\title{
Battery Cells for Electric Vehicles
}

\author{
Putri Nur Halimah ${ }^{1,2}$, Samuel Rahardian ${ }^{1,2}$, Bentang Arief Budiman ${ }^{1,2^{*}}$ \\ ${ }^{1}$ Faculty of Mechanical and Aerospace Engineering, Institut Teknologi Bandung, Indonesia \\ ${ }^{2}$ National Center for Sustainable Transportation Technology, Bandung, Indonesia \\ *Email: bentang@ftmd.itb.ac.id
}

\begin{abstract}
The shifting trend of conventional to the electric drivetrain in automotive industries makes batteries become the most favorable energy storage. There are three types of battery cells that are commonly used for electric vehicles i.e., cylindrical cells, pouch cells, and prismatic cells. The use of active material such as lithium-ion in the battery of electric vehicles could bring some issues related to the safety field. For that reason, comprehensive research on battery failure analysis needs to be conducted. This paper reviews the recent progress of the use of battery cells in electric vehicles and some challenges which must be considered to assure their safety. There are a lot of studies on battery failure analysis, which mainly focuses on the appearance of a short circuit as the main cause of the thermal runaway event. Several proposals on predicting short circuits in the battery due to various loading are comprehensively discussed. Those research results can be considered to establish regulations in designing battery protectors.
\end{abstract}

Keywords

Battery technology; Electric vehicle; Failure analysis; Lithium-ion; Safety

\section{Introduction}

In recent years, the use of energy sources in almost every sector of the world is gradually shifting into renewable energy such as wind [1], solar [2], waves [3], and geothermal [4]. The shifting is also accompanied by research and development of sustainable technologies, which can significantly reduce air pollution. One of the major contributors to creating massive air pollution is the use of fossil fuels for road transportation [5]. Thus, it has been predicted that the internal combustion engine that consumes a lot of fossil fuel will be substituted by the electric-based engine by the year 2025 [6]. At least, there are three main reasons which can push this transformation: (1) regulation of gas emission that getting tougher, (2) potential zero-emission of electric vehicles (EV) especially when the electrical energy sources come from renewable energy power plant, and (3) production and maintenance costs of EV which decreasing significantly.

In implementing EV as main road transportation, battery technology is still a challenging problem. Even though the battery is a common energy storage tool, problems such as high production cost, low energy density, and safety issues must be solved. An effort to reduce the high production cost and low energy density of the batteries has been proposed by, for example, integrating the $\mathrm{EV}$ and grid services so that $\mathrm{EV}$ owners can do a business of electric energy storage and take more benefits due to their ownership [7, 8]. Another idea to tackle these problems is by designing lightweight structures [6]. However, this must be followed by an assurance that the structures able to bear static and dynamic loading [9-11]. These ideas can be an alternative way before the low cost, and high energy density batteries are found $[12,13]$. For safety issues, the battery explosion might occur if the liquid material inside the battery is exposed to the air when an accident or crash event occurred $[14,15]$.

In this review, three types of battery cells, which are commonly used as the energy storage in EV are comprehensively discussed, including the advantages and disadvantages of each types. The understanding of difference among those three types is important to evaluate whether the type is suitable for various kinds of EV. The discussion focuses on safety issues, particularly on their failure mechanisms, which further contributes in recommending the design of battery protector. This recent research progress review could also be a good approach for future work in determining battery protectors' regulations to lessen safety issues in battery technology.

\section{Types of Battery Cells}

The battery cell is the smallest unit of battery packs or simply the single unit of a battery. There are three kinds of battery cells which are commonly used in EV, i.e., cylindrical cell, pouch cell, and prismatic cell $[16,17]$, 
as shown in Figure 1. Even though there are various kinds of battery cells, the most common material that is used as the constituent material remains identic, i.e., lithium-ion. Lithium-ion is favorable due to its prominent properties of relatively high energy density. This means it can store a high amount of energy in a small volume [18]. Nevertheless, it also has several disadvantages, such as it requires high production cost, it contains flammable material, and it could lead to an explosion during an accident or crash event. Thus, lithium-ion needs a proper battery casing to protect the material inside, which can avoid any trouble in further utilization.

Cylindrical cell, which is widely used in all models of Tesla Cars, has the highest production cost amongst all types [19]. There are several manufacturers of the cylindrical cell, such as Panasonic, co. Ltd and LG Chem, co. Ltd. In Indonesia, a cylindrical cell is developed in Sebelas Maret University via a laboratoryscale factory of the cylindrical battery cell (see Figure 1a). The research focuses on the reduction of production costs and the improvement of durability.

The most distinguished advantage of the cylindrical cell is, it needs no additional mechanism to control the pressure's change during the charging/discharging mode. This is due to the cylindrical case that made of metal which is relatively strong to maintain the cell's shape. Another advantage of cylindrical cells related to its shape is that it has a slender shape, so it can be densely packed to be conveniently arranged in almost any vehicles' available spaces.

However, because of the use of metal-based casing, the cylindrical cell usually has a heavier weight per energy storage compared to a pouch or prismatic battery. For designing EV, this may become an advantage because it can be positioned in the bottom side of the vehicle and thus lowering the center of gravity as designed by Tesla Car (see Figures 2a and 2b). Another disadvantage of the cylindrical cell is on designing a wiring and battery management system, which is usually more complicated than other battery types.

Figure $1 \mathrm{~b}$ shows a pouch cell battery produced by the Center for Nanoscience and Technology, Institut Teknologi Bandung. The most prominent advantage of this battery type is on their lower weight per energy storage compared to a cylindrical cell. This type is mostly used for devices that require light weight such as drones, electronic devices, and so on. Applying this battery type for an electric vehicle might not be beneficial since the casing is not designed to protect the battery from heavy loading. The additional battery packing that can protect the pouch battery cell might be required.

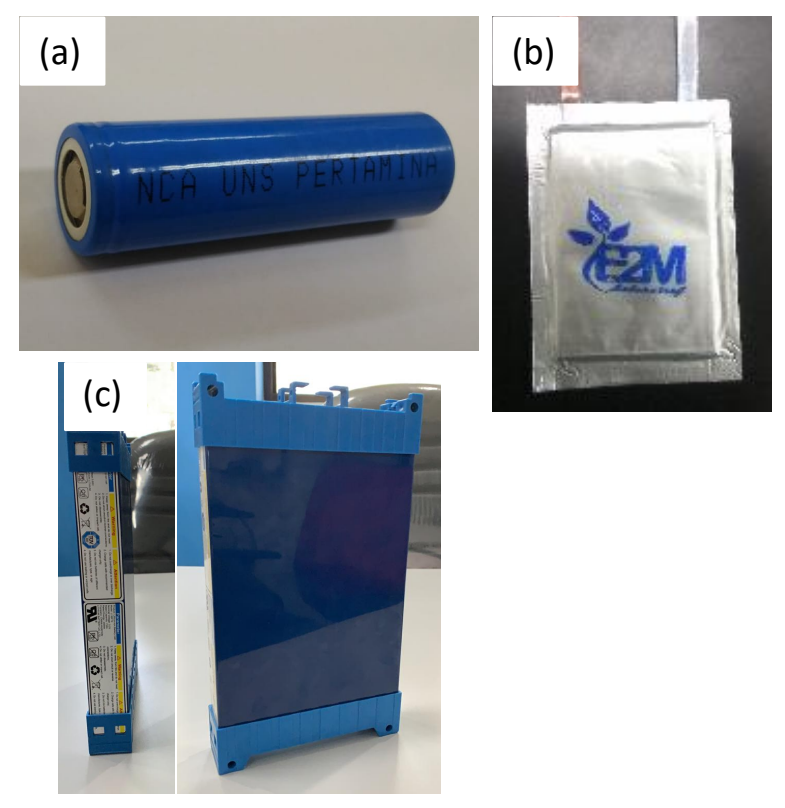

Figure 1 Three kinds of commonly used battery cells: (a) cylindrical cell, (b) pouch cell, and (c) prismatic cell.
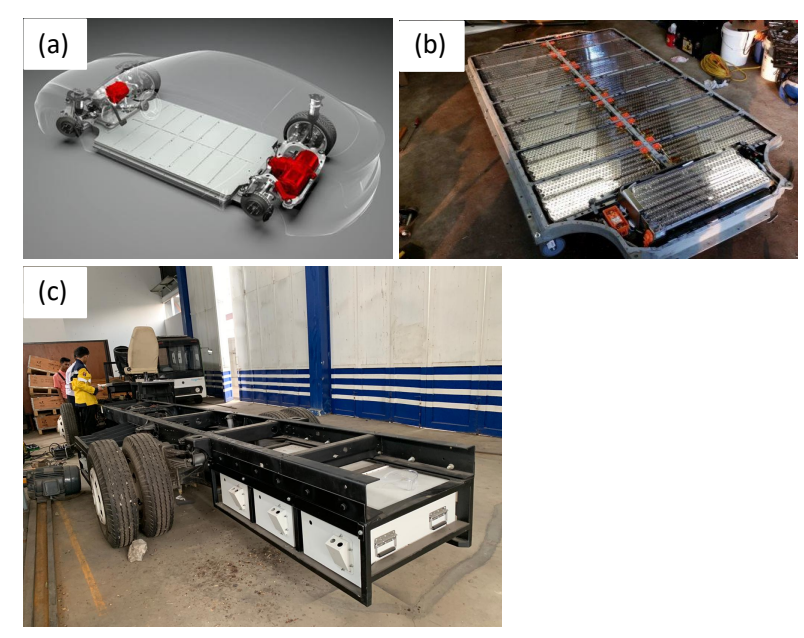

Figure 2 (a) battery packs in Tesla Cars are located under the floor [20], (b) the configuration of battery packs in Tesla Cars is divided into 16 packs, and the cylindrical cell is vertically arranged [21], and (c) prismatic battery in electric bus chassis.

The last battery type is a prismatic cell (see Figure 1c). The foremost advantage of this type is on very high energy density compared to other battery types. The battery packing of the prismatic cell is usually compact; thus, it is suitable for heavyweight EV such as bus, truck, or even for tractor and ship. Figure 2c shows prismatic battery applied to medium-sized electric bus chassis. The battery is attached below the chassis to lower the bus's center of gravity. Another important 
advantage of this battery is on developing a battery management system. The designing battery management system is usually less complicated compared to other battery types. However, since the manufacturing cost of each battery cells is more expensive than other battery types, it will encounter more losses when the damage occurs. Therefore, the quality control of prismatic battery cell manufacturing is required to assure the endurance and reliability during the battery is used.

\section{Failure Analysis of Battery Cells}

There were already many studies related to crashworthiness analysis of battery cells, especially for 18650 's cylindrical cell [22-24]. For example, the work by Juner Zhu et al. reported that the most important key to determining the battery safety is to measure the axial shortening of the cylindrical battery during the crash event [22]. The result shows that the axial shortening of the battery should not exceed $3 \mathrm{~mm}$ in order to avoid short-circuit due to greatly-damaged separator. The deformation sequence is initially dominated by shell casing of the battery, then followed by the indentation to the jelly roll (inner material of the battery).

Another work by Sahraei et al. reported that the deflection of lateral indentation should not exceed $4 \mathrm{~mm}$ from the indentation point [23]. This work combines numerical and experimental approaches. There are four kinds of loading configuration performed using the finite element (FE) model and experimental analysis. The results reported that the location of the failure, which could trigger the short-circuit is $4 \mathrm{~mm}$ from the indentation point.

Even though the research used a simpler FE model, good and accurate results are obtained because the FE model and experimental test result showed the identic location where short-circuit has occurred. Hence, though it is a simplified model, it is reliable enough to simulate the lateral loading on a cylindrical cell. These two cases, axial loading and bending loading, are the most common case in the battery's crash problem because when a crash happens, the battery will most probably experience at least one of these two possible cases.

Pouch battery packaging offers flexibility due to the minimalistic approach for packaging. Pouch battery consists of cathode, separator, and separator stacked then sealed by flexible foil [25]. Sahraei et al. conducted several experiments to investigate the mechanical integrity of the pouch battery. Mechanical integrity was important for pouch battery design due to its cover only using flexible foil, which has low mechanical strength.
Mechanical integrity is evaluated by compression between two plates, lateral indentation by hemispherical punch, unconfined axial crash in width and length direction, confined compression in width direction, and three-point bending. Each testing conducted for bare cell and pouched cells except for confined compression. FE simulation also conducted to predict the failure for lateral compression, punch indentation, unconfined, and confined compression [23].

For high power demand applications, prismatic cell packaging would be preferred. The prismatic cell battery has a design like a prismatic box with its electrode and separator shape like a long stripe. The anode, cathode, and separator wounded up and then pressed into the container. By using wounding and pressing to make the cell, packaging density would be improved. However, due to the wounding process, the cell would bear higher stress around the bent portion that could result in battery mechanical failure or short circuit [25].

Duh et al. have conducted experimental work to find thermal stability for the commercialized prismatic battery. Seven types of cellphone battery tested, which has used prismatic type battery to find the characteristic and thermal runaway propagation. When the temperature reached a crucial temperature, the flame will be ignited, and thermal failure would occur. From the experimental data, one type of prismatic battery reaches the maximum temperature of $675.6^{\circ} \mathrm{C}$ and a maximum self-heat rate of $11,860^{\circ} \mathrm{C} / \mathrm{min}$ when the thermal runaway occurs [26]. Another work from Lee et al. shows that failure mechanism due to swelling of prismatic battery that has been preserved in long-term storage would reduce the battery voltage. The swelling was observed in a battery that has been used one year after stored in two years. Further investigation by disassembling the battery shows that the gas bubble was trapped between the can body and jelly roll. Side reactants also identified by different colors near the center of anode [27].

\section{Conclusion}

This review paper is focused on comparing the three kinds of battery cells, i.e., cylindrical cells, prismatic cells, and pouch cells, in terms of the advantages and disadvantages when it is applied to an electric vehicle. It is concluded that a cylindrical cell has a strong benefit related to its shape and casing material, in which the metal casing could retain the cylindrical shape from bulking during the charging/discharging mode. Moreover, its slender shape makes it convenient enough to be placed in small space, such as below the car's floor. The prismatic battery offers high power density 
due to its compact packaging and can bear high mechanical stress from its cover. However, a prismatic battery cell could bear high stress at the corner of the bending cell due to its packaging process. Gas also could be trapped and make the battery swollen and reducing its voltage. Pouch battery can be used in many applications because of its minimalistic packaging and high-power density. Pouch battery cells consist of several stacked cells then sealed by thin foil. Thin foil sealing offers flexibility but on the same hand, lower its mechanical integrity. Pouch battery mechanical integrity need to be investigated further to ensure the safety aspect for battery usage.

\section{Acknowledgment}

This paper is supported by USAID through Sustainable Higher Education Research Alliances (SHERA) program with grant number IIE00000078-ITB-1.

\section{References}

[1] F. B. Juangsa, B. A. Budiman, M. Aziz, and T. A. F. Soelaiman, "Design of an airborne vertical axis wind turbine for low electrical power demands," International Journal of Energy and Environmental Engineering, vol. 8, pp. 293$301,2017$.

[2] M. Nizam and F. R. Wicaksono, "Design and Optimization of Solar, Wind, and Distributed Energy Resource (DER) Hybrid Power Plant for Electric Vehicle (EV) Charging Station in Rural Area," in 2018 5th International Conference on Electric Vehicular Technology (ICEVT), 2018, pp. 41-45.

[3] R. Pelc and R. M. Fujita, "Renewable energy from the ocean," Marine Policy, vol. 26, pp. 471-479, 2002.

[4] E. Barbier, "Geothermal energy technology and current status: an overview," Renewable and sustainable energy reviews, vol. 6, pp. 3-65, 2002.

[5] O. Edenhofer, Climate change 2014: mitigation of climate change vol. 3: Cambridge University Press, 2015.

[6] F. Arifurrahman, B. A. Budiman, and M. Aziz, "On the Lightweight Structural Design for Electric Road and Railway Vehicles using Fiber Reinforced Polymer Composites-A Review," Int. J. Sustain. Transp. Technol., vol. 1, pp. 21-29, 2018.

[7] M. Aziz and B. A. Budiman, "Extended utilization of electric vehicles in electrical grid services," in 2017 th International Conference on Electric Vehicular Technology (ICEVT), 2017, pp. 1-6.

[8] M. Aziz, M. Huda, B. A. Budiman, E. Sutanto, and P. L. Sambegoro, "Implementation of Electric Vehicle and Grid Integration," in 2018 5th International Conference on Electric Vehicular Technology (ICEVT), 2018, pp. 9-13.

[9] I. P. Nurprasetio, M. Aziz, B. A. Budiman, and A. A. Afwan, "Development of Static and Dynamic Online Measurement System for Ground Vehicles," in 2018 5th International Conference on Electric Vehicular Technology (ICEVT), 2018, pp. 31-35.

[10] F. Arifurrahman, I. Indrawanto, B. A. Budiman, P. L. Sambegoro, and S. P. Santosa, "Frame modal analysis for an electric three-wheel vehicle," in MATEC Web of Conferences, 2018, p. 08001.

[11] F. Arifurrahman, B. A. Budiman, and S. P. Santosa, "Static Analysis of an Electric Three-Wheel Vehicle," in 2018 th
International Conference on Electric Vehicular Technology (ICEVT), 2018, pp. 218-223.

[12] V. Natalia, F. Rahmawati, A. Wulandari, and A. Purwanto, "Graphite/Li 2 ZrO 3 anode for a LiFePO 4 battery," Chemical Papers, vol. 73, pp. 757-766, 2019.

[13] F. Iskandar, O. B. Abdillah, E. Stavila, and A. H. Aimon, "The influence of copper addition on the electrical conductivity and charge transfer resistance of reduced graphene oxide (rGO)," New Journal of Chemistry, vol. 42, pp. 16362-16371, 2018.

[14] W.-J. Lai, M. Y. Ali, and J. Pan, "Mechanical behavior of representative volume elements of lithium-ion battery modules under various loading conditions," Journal of Power Sources, vol. 248, pp. 789-808, 2014.

[15] H. Fadillah, A. Jusuf, S. P. Santosa, and T. Dirgantara, "Liion NCA Battery Safety Assessment for Electric Vehicle Applications," in 2018 5th International Conference on Electric Vehicular Technology (ICEVT), 2018, pp. 172-178.

[16] P. L. Sambegoro, B. A. Budiman, E. Philander, and M. Aziz, "Dimensional and Parametric Study on Thermal Behaviour of Li-ion Batteries," in 2018 5th International Conference on Electric Vehicular Technology (ICEVT), 2018, pp. 123127.

[17] C. Arcus. (2016, 8 April). Tesla Model S Battery vs Nissan LEAF Battery vs Chevy Volt Battery. Available: https://cleantechnica.com/2016/01/06/a-tale-of-3-batterypacks/

[18] A. F. Burke, "Batteries and ultracapacitors for electric, hybrid, and fuel cell vehicles," Proceedings of the IEEE, vol. 95, pp. 806-820, 2007.

[19] C. Iclodean, B. Varga, N. Burnete, D. Cimerdean, and B. Jurchiş, "Comparison of Different Battery Types for Electric Vehicles," in IOP conference series: materials science and engineering, 2017, p. 012058.

[20] C. Morris. (2019, 16 Mar). Tesla's Battery Leadership Protected In Secrecy. Available: https://cleantechnica.com/2019/01/25/inside-teslas-secretintense-focus-on-batteries/

[21] K. Field. (2018, 8 April). Yes, Tesla Recycles All Of Its Spent Batteries \& Wants To Do More In The Future. Available: https://cleantechnica.com/2018/06/07/yes-tesla-recyclesall-of-its-spent-batteries-wants-to-do-more-in-the-future/

[22] J. Zhu, X. Zhang, E. Sahraei, and T. Wierzbicki, "Deformation and failure mechanisms of 18650 battery cells under axial compression," Journal of Power Sources, vol. 336, pp. 332-340, 2016.

[23] E. Sahraei, J. Campbell, and T. Wierzbicki, "Modeling and short circuit detection of 18650 Li-ion cells under mechanical abuse conditions," Journal of Power Sources, vol. 220, pp. 360-372, 2012.

[24] P. N. Halimah, S. P. Santosa, A. Jusuf, and T. Dirgantara, "The Concept of Sandwich Panel Structures for Battery Protections in Electric Vehicles Subjected to Ground Impact," in 2018 5th International Conference on Electric Vehicular Technology (ICEVT), 2018, pp. 142-146.

[25] E. Maiser, "Battery packaging-Technology review," in AIP Conference Proceedings, 2014, pp. 204-218.

[26] Y.-S. Duh, K. H. Lin, and C.-S. Kao, "Experimental investigation and visualization on thermal runaway of hard prismatic lithium-ion batteries used in smart phones," Journal of Thermal Analysis and Calorimetry, vol. 132, pp. 1677-1692, 2018.

[27] S.-H. Lee and I.-H. Ko, "Failure Analysis of Swelling in Prismatic Lithium-Ion Batteries During Their Cycle Life After Long-Term Storage," Journal of Failure Analysis and Prevention, vol. 18, pp. 554-561, 2018. 